\title{
Unilateral spatial neglect
}

\author{
Taro Shimizu, ${ }^{1}$ Tomoya Abe, ${ }^{2}$ Yasutoshi Akasaki, ${ }^{2}$ Hideaki Kamiishi ${ }^{2}$
}

'Department of Diagnostic and Generalist Medicine, Dokkyo Medical University, Shimotsugagun, Tochigi, Japan ${ }^{2}$ Department of Emergency Medicine, Tokyo-West Tokushukai Hospital, Akishima, Tokyo, Japan

\section{Correspondence to}

Dr Taro Shimizu;

shimizutaro7@gmail.com

Accepted 29 October 2020

\section{DESCRIPTION}

A 75 -year-old woman presented with acute behavioural change. She was well until 6 hours prior, when she looked bizarrely while on cooking. Her son spoke to her and noticed that she was staring at her right side. He approached her from her left side and talked to her, but she did not seem to notice him as if she was ignoring him. In addition, the son also noticed that only the left half of the leeks laid out on the cutting board remained uncut. The right half of the leeks had already been cut and cooked in a pot of miso soup. Besides, she seemed that she could not find a salt jar, which was located to her left. Despite the fact that she faced difficulty in paying attention to her left side, she did not ask her son for help as she did not seem to be troubled by her situation. He thought something wrong was happening and brought her to the hospital. She had no fever, headache or weakness. On examination, she consistently turned her head and gaze to the right. She had no contralesional weakness. When instructed to point the middle of the stethoscope tube, she grabbed the right quarter of the tube. Diffusion-weighted MRI revealed highintensity signals in the right inferior parietal lobule (figure 1); MR angiography showed severe narrowing of the proximal right middle cerebral artery (figure 2). She was diagnosed with unilateral spatial neglect due to acute ischaemic stroke.

Unilateral spatial neglect is characterised by symptoms of not only ignoring the contralesional side but also being ipsilesionally attracted to stimuli. ${ }^{12}$ In the acute phase, the patient may show an ipsilesional deviation of the head and eyes. ${ }^{3}$ The damaged lesion is typically located in the inferior parietal lobule region, as in this case. Patients who present with behavioural

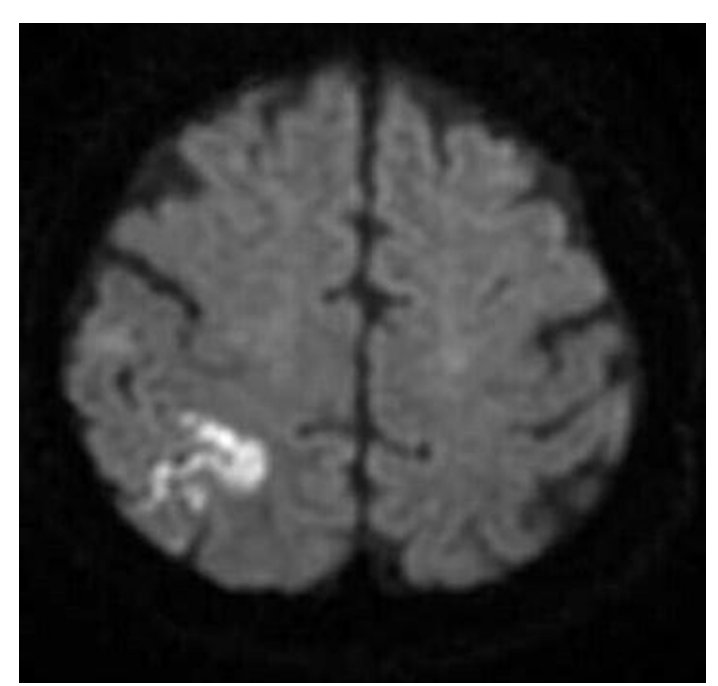

Figure 1 Diffusion-weighted MRI revealed highintensity signals in the right inferior parietal lobule.

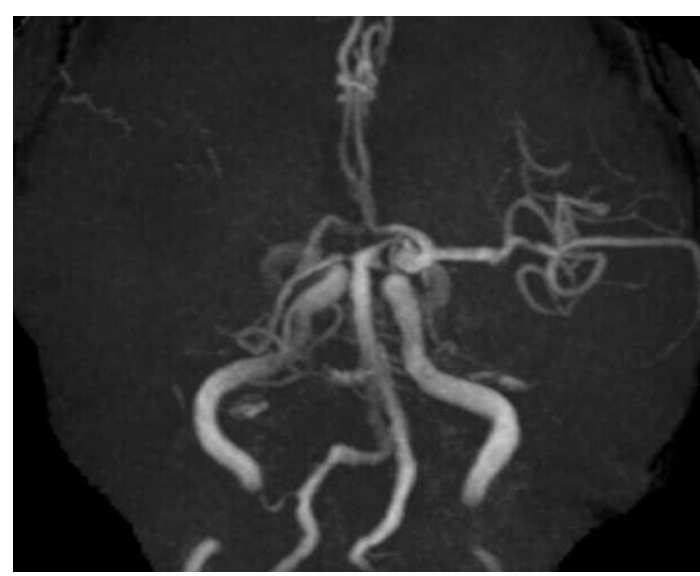

Figure 2 MR angiography showed severe narrowing of the proximal right middle cerebral artery.

\section{Patient's perspective}

Patient's son: It was as if my mother could not see the left half, or rather, she was ignoring it.

\section{Learning points}

Patients with unilateral spatial neglect, caused by the lesion in the inferior parietal lobule, sometimes present just with behavioural abnormalities.

- Patients with 'behavioural abnormalities' are challenging to examine.

- An astute observation on the deviation of the head and eyes may lead to a rapid and accurate diagnosis.

abnormalities are challenging to examine, but an astute observation on the deviation of the head and eyes may lead to a rapid and accurate diagnosis.

Contributors TS, TA, YA and HK created the manuscript, and TS revised the manuscript.

Funding The authors have not declared a specific grant for this research from any funding agency in the public, commercial or not-for-profit sectors.

Competing interests None declared.

Patient consent for publication Obtained.

Provenance and peer review Not commissioned; externally peer reviewed.

\section{REFERENCES}

1 Mark VW, Kooistra CA, Heilman KM. Hemispatial neglect affected by non-neglected stimuli. Neurology 1988;38:1207-11.

2 Chokron S, Peyrin C, Perez C. Ipsilesional deficit of selective attention in left homonymous hemianopia and left unilateral spatial neglect. Neuropsychologia 2019;128:305-14.

3 Gammeri R, lacono C, Ricci R, et al. Unilateral spatial neglect after stroke: current insights. Neuropsychiatr Dis Treat 2020;16:131-52. 
Copyright 2020 BMJ Publishing Group. All rights reserved. For permission to reuse any of this content visit https://www.bmj.com/company/products-services/rights-and-licensing/permissions/

BMJ Case Report Fellows may re-use this article for personal use and teaching without any further permission.

Become a Fellow of BMJ Case Reports today and you can:

- Submit as many cases as you like

Enjoy fast sympathetic peer review and rapid publication of accepted articles

Access all the published articles

Re-use any of the published material for personal use and teaching without further permission

Customer Service

If you have any further queries about your subscription, please contact our customer services team on +44 (0) 2071111105 or via email at support@bmj.com.

Visit casereports.bmj.com for more articles like this and to become a Fellow 